\title{
PLURALISME HUKUM DI INDONESIA DARI SUDUT PANDANG ANTROPOLOGI HUKUM
}

\author{
Siti Shofiyyah Pesnira \\ Email: sitishofiyyah 02@gmail.com \\ No BP: 2110003600074 \\ Universitas Ekasakti Padang
}

\section{A. PENDAHULUAN}

Antropologi secara etimologis berasal dari bahasa Yunani. Kata anthropos berarti manusia dan logosberarti ilmu pengetahuan. Jadi antropologi adalah ilmu yang mempelajarimanusia. Dalam ilmu antropologi hukum dipelajari mengenai peran, status atau kedudukan,nilai, norma juga kebudayaan. Semua ini sangat erat kaitannya dengan ilmu antropologihukum. Sebelum berdirinya Komunisme, magistrat-magistrat Tiongkok, misalnya, tidak berurusan dengan menginterpretasi dan menerapkan aturan hukum untuk kasus-kasus konflik yang terjadi, namun menggunakan aturan hukum hanya sebagai pedoman teladanteladanyang sangat berguna, tetapi tidak harus diteladani dalam kasus konkrit. Dalam antropologihukum tidak dapat membatasi diri pada isi peraturan-peraturan hukum dan bentuk bentuk sanksinya, tapi yang perlu diketahui dengan jelas adalah proses pembentukan hukumnya. Antropologi hukum adalah ilmu yang mempelajari tentang manusia dan budayanya khusus dibidang hukum. Kebudayaan hukum yang dimaksud adalah kekuasaan yangdigunakan oleh penguasa untuk mengatur masyrakat agar tidak melanggar kaidah-kaidah sosial yang telah ada didalam suatu masyarakat itu sendiri. Hukum dipahami sebagai milik sebuah masyarakat sebagai suatu keseluruhan.Konsekuensi logisnya, suatu masyarakat dianggap hanya memiliki satu sistem hukum saja yang mengendalikan perilaku semua anggotanya. Tanpa sedikit pun menyelidiki kontrol-kontrol sosial yang bekerja pada tingkat sub masyarakat, sub kelompok (misalnya, perkumpulan, kelompok orang yang hidup serumah, dan kelompok kerabat) telah secara apriori 
dikecualikan dari kemungkinan mengatur perilaku anggotanya dengan sistem yangditerapkan oleh pemimpin kelompok dalam keputusan-keputusan khusus sistem yang berdasarkan ciri-ciri khas esensinya amat sangat menyerupai hukum pada masyarakat yang meliputi semua kalangan. Hukum juga diartikan sebagai disiplin (system ajaran tentang kenyataan) dan ilmu pengetahuan (yakni ilmu hukum). Sebagai ilmu pengetahuan, maka hukum di katakan mencangkup ilmu tentang kaidah, ilmu tentang pengertian dasar sistem hukum dan ilmu kenyataan (seperti misalnya sosiologi hukum, antropologi hukum, psikologi hukum,perbandingan hukum dan sejarah hukum) Pengertian lain tentang hokum yaitu bahwa hokum diartikan sebgai proses pemerintahan. Proses pemerintahan itu mencangkup peraturan, pemerintahan dalam arti sempit, penanggulangan serta peradilan. Hukum diartikan pula sebagai jalinan nilai. Nilaitersebut merupakan konsepsi abstrak di dalam diri manusia mengenai apa yang dianggap baikserta apa yang dianggap buruk. Hukum diartikan sebagai nilai yang merupakan salah satu unsur pandangan manusia mengenai hal-hal yang seharusnya dianuti karena dianggap baik,dan hal-hal yang seharusnya dihindari karena dianggap buruk.

\section{B. PEMBAHASAN}

Melalui studi - studi antropologi mengenai sistem pengendalian sosial (social control) di berbagai komunitas masyarakat di dunia, kalangan ahli antropologi memberi kontribusi yang sangat penting dan bermakna dalam pengembangan konsep hokum yang secara nyata berlaku dan dioperasikan dalam kehidupan masyarakat. Hal ini karena para ahli antropologi mempelajari hokum bukan semata-semata sebagai produksi dari hasil abstraksi logika sekelompok orang yang diformulasikan dalam bentuk peraturan perundang-undangan, tetapi lebih mempelajari hukum sebagai perilaku sosial. Dimana hukum dalam perspektif antropologi dipelajari sebagai bagian yang integral dari kebudayaan secara keseluruhan, karena itu hukum 
dipelajari sebagai produk dari interaksi sosial yang dipengaruhi oleh aspek-aspek kebudayaan yang lain, seperti politik,ekonomi. ideologi, religi. (Pospisil, 1971);atau hukum dipelajari sebagai proses social yang berlangsung dalam kehidupan masyarakat. Berdasarkan hal tersebut, hukum dalam perspektif antropologi bukan semata mata berwujud peraturan perundang-undangan yang diciptakan oleh Negara (state law), tetapi juga hukum dalam wujudnya sebagai peraturanperaturan lokal yang bersumber dari suatu kebiasaan masyarakat (customary Imwfolk law), termasuk pula di dalamnya mekanisme-mekansime pengaturan dalam masyarakat (self regulation) yang juga berfungsi sebagai sarana pengendalian sosial (legal order).

Adapun studi - studi antropologis mengenai hukum diawali dengan munculnya pertanyaan-pertanyaan mendasar: apakah hukum itu ?; dan apakah hukum itu terdapat dalam setiap bentuk masyarakat ? (Nader,1965:4; Bohannan, 1967:4; Hoebel,1968:187). Untuk menjawab pertanyaan diatas menjadi menarik untuk mengungkapkan diskusi dari dua ahli antropologi ternama, yaitu A.R, Radcliffe-Brown dan Bronislaw Malinowski, yang memberikan pandangan- nya masing - masing mengenai hukum, sebagaimana diuraikan dalam Nader (1965:4-5); Koentjaraningrat (1989:28-9) seperti berikut:

1. Di satu sisi, hukum dalam pandangan Radcliffe-Brown adalah suatu system pengendalian sosial yang hanya muncul dalam kehidupan masyarakat yang berada dalam suatu bangunan Negara, karena hanya dalam suatu organisasi sosial seperti Negara terdapat pranata-pranata hukum misalnya polisi, pengadilan, penjara sebagai alat-alat Negara yang mutlak harus ada untuk menjaga keteraturan dalam masyarakat. Karena dalam masyarakat bersahaja yang tidak terorganisasi secara politis sebagai suatu Negara tidak mempunyai hukum. Walaupun tidak mempunyai ketertiban 
social dalam masyarakat tersebut diatur dan dijaga oleh tradisi-tradisi yang ditaati oleh warga masyarakat secara otomatis-spontan (automatic-sponta-neous to tradition).

2. Di sisi lain, Malinowski berpendapat,bahwa hukum tidak semata - mata terdapat dalam masyarakat yang terorganisasi suatu Negara, tetapi hukum sebagai sarana pengendalian sosial (legal order) terdapat dalam setiap bentuk masyarakat. Hukum dalam kehidupan masyarakat bukan ditaati karena adanya tradisi ketaatan yang bersifat otomatis-spontan, seperti dikatakan Radcliffe-Brown, tetapi karena adanya prinsip timbal-balik (principle of reciprocity) dan prinsip publisitas (principle of public-city) misalnya sistem pertukaran sosial yang berkembang dalam masyarakat Trobriand menjadi pengikat sosial dan daya dinamis yang menggerakkan kehidupan ekonomi dan sosial masyarakat melalui prinsip resiprositas atau timbal - balik dalam bentuk pertukaran benda dan tenaga, menggerakkan hubungan - hubungan ekonomi, pertukaran jasa antar kerabat, menggerakkan kehidupan kekerabatan, sistem pertukaran mas kawin, dan juga menggerakkan hubungan antar kelompok dalam bentuk upacara - upacara yang berlangsung dalam kehidupan bersama.

Dari pandangan dua ahli antropologi di atas dapat dikatakan, bahwa apabila hukum diberi pengertian yang sempit, hanya sebagai sistem pengendalian sosial yang diciptakan oleh lembaga legislatif dan diterapkan oleh aparat penegakan hokum seperti polisi, pengadilan, jaksa, atau penjara dalam kehidupan organisasi negara, maka hukum diartikan bahwa dimana masyarakat-masyarakat sederhana yang tidak terorganisasi sebagai suatu Negara tidak memiliki hukum. Tetapi, kalau hokum diberi pengertian yang lebih luas,yaitu sebagai prosesproses pengendalian social yang didasarkan pada prinsip resiprositas dan publisitas yang secara empiris berlangsung dalam kehidupan masyarakat, maka semua bentuk masyarakat 
betapapun sederhananya memiliki hukum dalam bentuk mekanisme - mekanisme yang diciptakan untuk menjaga keteraturan sosial atau sebagai sarana pengendalian sosial. Wacana antropologis mengenai hokum dalam perkembangan selanjutnya memperoleh elaborasi dar kalangan antropolog yang lain. Konsep hukum yang dikemukakan Malinowski memperole komentar dan kritik dari Bohannan (1967:45-9), yang pada dasarnya menyatakan seperti berikut:

1. Mekanisme resiprositas (reciprocity) dan publisitas (publicity) sebagai kriteria untuk mengatur hak dan kewajiban dalam kehidupan masyarakat pada dasarnya bukan merupakan hukum seperti dimaksudkan Malinowski, tetapi hanya sebagai suatu kebiasaan (custom) yang digunakan masyarakat untuk menjaga keteraturan sosial.

2. Pengertian hukum harus dibedakan dengan tradisi (tradition) atau kebiasaan atau lebih spesifik, norma hukum mempunyai pengertian yang berbeda dengan kebiasaan. Norma hukum adalah peraturan hukum yang mencerminkan tingkah laku yang seharusnya (ought) dilakukan dalam hubungan antar individu. Sedangkan, kebiasaan merupakan seperangka norma yang diwujudkan dalam tingkah laku dan berlangsung dalam kurun waktu yang lama. Pada umumnya kebiasaan dapat disamakan dan disesuaikan dengan peraturan-peraturan hukum, tetapi kebiasaan tersebut dapat juga bertentangan dengan norma - norma hukum. Ini berarti, peraturan hukum dan kebiasaan adalah dua institusi yang sama-sama terwujud dalam bentuk norma -norma yang mengatur perilaku masyarakat dalam hubungan antar individu, dan juga sama-sama berfungsi sebagai sarana pengendalian sosial dalam kehidupan masyarakat. 
3. Walaupun kebiasaan dan peraturan hukum saling berbeda satu sama lain, karena kebiasaan terwujud sebagai institusi non hukum dan peraturan merupakan institusi hukum, tetapi dalam masyarakat selalu ditemukan kedua bentuk institusi tersebut (institusi hukum dan institusi non hukum). Norma - norma hokum dalam masyarakat cenderung mengabaikan atau menggusur atau sebaliknya memfungsikan keberadaan kebiasaan - kebiasaan sebagai institusi non hukum dalam penyelesaian kasus - kasus sengketa yang terjadi dalam masyarakat.

4. Peraturan - peraturan hukum juga mengembangkan kebiasaan - kebiasaan sebagai institusi hukum melalui proses pelembagaan ulang (institutionnalized) dan dinyatakan ulang (restated), sehingga peraturan hukum juga dikatakan sebagai suatu kebiasaan yang telah dilembagakan kembali untuk tujuan - tujuan yan ingin dicapai hukum tersebut. Dengan demikian, apabila dihubungkan dengan pengertian hukum yang dikemukakan Malinowski, maka peraturan hukum diartikan sebagai seperangkat kewajiban yang dipandang sebagai hak warga masyarakat dan kewajiban bagi warga masyarakat yang lain, yang telah dilembagakan ulang menjadi institusi hukum, untuk suatu tujuan agar kehidupan masyarakat secara terus menerus dapat berlangsung dan berfungsi dengan keteraturan yang dikendalikan olehinstitusi hukum. Karena itu, dikatakan bahwa resiprositas berada pada basis kebiasaan, tetapi kebiasaan yang telah dilembagakan sebagai norma hukum melalui tahapan yang disebut double institution-nnalization of norms (Bohannan, 1967:48).

Lebih lanjut, konsep mengenai hokum yang dikemukakan Malinowski juga mem- 
peroleh komentar dan kritik dari Pospisil (1967: 25-41; 1971:39-95), yang pada pokoknya menyatakan seperti berikut:

1. Pengertian hukum yang dikemukakan Malinowski dipandang terlalu luas,sehingga hukum yang dimaksudkan juga mencakup pengertian kebiasaan kebiasaan (customs), dan semua bentuk kewajiban -kewajiban yang berhubungan dengan aspek religi dan juga kewajiban -kewajiban yang bersifat moral dalam kehidupan masyarakat.

2. Hukum pada dasarnya adalah suatu aktivitas kebudayaan yang mempunyai fungsi sebagai alat untuk menjaga keteraturan sosial atau sebagai sarana pengendalian social (social control) dalam masyarakat. Karena itu, untuk membedakan peraturan hukum dengan norma - norma lain, yang sama - sama mempunyai fungsi sebagai sarana pengendalian sosial dalam masyarakat, maka peraturan hukum dicirikan mempunyai 4 atribut hukum (attributes of law), yaitu:

(1). Atribut Otoritas (Attribute ofAuthority), yaitu peraturan hokum adalah keputusan - keputusan dari pemegang atoritas untuk menyelesaikan sengketa atau ketegangan sosial dalam masyarakat, karena adanya ancaman terhadap keselamatan warga masyarakat, keselamatan pemegang otioritas, atau ancaman terhadap kepentingan umum.

(2). Atribut dengan maksud untuk diaplikasikan secara Universal (Attribut of Intention of Universal33 Aplication), yaitu keputusan-keputusan dari pemegang otoritas tersebut dimaksudkan sebagai keputusan - keputusan yang juga akan diaplikasikan terhadap peristiwa - peristiwa yang sama secara universal. 
(3). Atribut Obligasio (Attribute of Obligatio), yaitu keputusan-keputusan dari pemegang otoritas tersebut mengandung suatu pernyataan bahwa pihak pertama memiliki hak untuk menagih sesuatu dari pihak kedua dan pihak kedua mempunyai kewajiban untuk memenuhi hak pihak pertama tersebut sepanjang mereka masih hidup.

(4). Atribut Sanksi (Attribute of Sanction), yaitu keputusan- keputusan dari pihak pemegang otoritas tersebut juga disertai dengan penjatuhan sanksi sanksi baik berupa sanksi yang bersifat fisik seperti hukuman badan dan penyitaan harta benda, atau sanksi nonfisik seperti dipermalukan di depan orang banyak, diasingkan dari pergaulan sosial, dibuat menjadi ketakutan, dimana basis konsep hukum yang menekankan atribut otoritas dan atribut sanksi juga dikemukakan oleh Hoebel untuk membedakan antara norma hukum dengan norma-norma lain yang juga mempunyai fungsi sebagai alat pengedalian masyarakat (social control).

Sstudi - studi antropologis mengenai hukum juga memberi perhatian pada fenomena kemajemukan hukum (legal pluralism) dalam kehidupan masyarakat. Dalam kaitan ini, Cotterrel (1995) menegaskan bahwa secara empiris dapat dijelaskan, hukum yang berlaku dalam masyarakat selain terwujud dalam bentuk hukum negara (state law), juga berwujud sebagai hukum agama (religious law), dan hukum kebiasaan (customary law). Tetapi, secara antropologis bentuk mekanisme-mekanisme pengaturan sendiri (inner order mechanism atau self-regulation ) dalam komunitas - komunitas masyarakat adalah merupakan hukum yang secara local berfungsi sebagai sarana untuk menjaga keteraturan sosial (F. von Benda-Beckmann, 1989J 1999) . Sedangkan pluralisme hukum secara umum didefinisikan sebagai suatu situasi di mana dua atau 
lebih sistem hukum bekerja secara berdampingan dalam suatu bidang kehidupan sosial vang sama ,atau untuk menjelaskan keberadaan dua atau lebih sistem pengendalian sosial dalam satu bidang kehidupan sosial (Griffiths), atau menerangkan suatu situasi di mana dua atau lebih sistem hukum berinteraksi dalam satu kehidupan sosial (Hooker), atau suatu kondisi di mana lebih dari satu sistem hukum atau institusi bekerja secara berdampingan dalam aktivitas aktivitas hukum yang berhubungan dalam satu kelompok masyarakat (F.von Benda-Beckmann).

Ajaran mengenai pluralisme hukum (legal pluralism) secara umum dipertentang kan dengan ideologi sentralisme hokum (legal centralism). Ideologi sentralisme hukum diartikan sebagai suatu ideologi yang menghendaki pemberlakuan hukum Negara (state law) sebagai satu satunya hukum bagi semua warga masyarakat, dengan mengabaikan keberadaan sistem - system hukum yang lain, seperti hukum agama, hukum kebiasaan, dan juga semua bentuk mekanisme mekanisme pengaturan local yang secara empiris berlangsung dalam kehidupan masyarakat. Dalam konteks ini, Griffiths (1986:12), menegaskan sentralisme hukum cenderung mengabaikan kemajemukan sosial dan budaya dalam masyarakat, termasuk di dalamnya norma - norma hukum lokal yang secara nyata dianut dan dipatuhi warga dalam kehidupan bermasyarakat, bahkan sering lebih ditaati dari pada hukum yang diciptakan dan diberlakukan oleh negara (state law). Karena itu, pemberlakuan sentralisme hukum dalam suatu komunitas masyarakat yang memiliki kemajemukan sosial dan budaya hanya merupakan sebuah kemustahilan.

Konsep pluralisme hukum yang dikemukakan Griffiths di atas pada dasarnya dimaksudkan untuk menonjolkan keberadaan dan interaksi sistem - sistem hokum dalam suatu masyarakat, antara hokum negara (state law) dengan sistem hokum rakyat (folk law) dan sistem hukum agama (religious law) dalam suatu kelompok masyarakat, Dalam kaitan ini, Tamanaha (1992:25-6) memberi komentar kritis terhadap konsep pluralisme dari Griffiths yang cenderung 
erfokus pada penekanan dikotomi keberadaan hukum negara dengan sistem - sistem hukum yang lain, seperti berikut:

1. Konsep pluralisme hukum dari Griffiths pada dasarnya dibedakan menjadi dua macam, yaitu pluralism yang kuat (strong legal pluralism) dan pluralisme yang lemah (weak legal pluralism). Pluralisme yang lemah merupakan bentuk lain dari sentralisme hukum (legal centralism), karena dalam kenyataannya hukum Negara (state law) mengakui adanya system -sistem hukum yang lain, tetapi hukum negara tetap dipandang sebagai superior, dan sementara itu sistem - sistem hukum yang lain bersifat inferior dalam hirarkhi sistem hokum negara. Contoh yang memperlihat- kan pluralisme hukum yang lemah(weak legal pluralism) adalah konsep pluralisme hukum dalam konteks interaksi sistem hukum pemerintah kolonial dengan sistem hukum rakyat (folk law) dan hukum agama (religious law) yang berlangsung di negara-negara jajahan.

2. Sedangkan, pluralism hukum yang kuat mengacu pada fakta adanya kemajemukan tatanan hukum dalam semua kelompok masyarakat yang dipandang sama kedudukannya, sehingga tidak terdapat hirarkhi yang menunjukkan sistem hukum yang satu lebih dominan dari system hukum yang lain. Untuk ini, teori Living Law dari Eugene Ehrlich yang menyatakan dalam setiap masyara kat terdapat aturan - aturan hokum yang hidup dari tatanan normative yang biasanya dikontraskan atau di pertentangkan dengan sistem hokum negara termasuk dalam kategori pluralisme hukum yang kuat (strong legal pluralism).

3. Selain itu, yang dimasukkan kategori pluralisme hukum yang kuat adalah teori Semiautonomous Social Field yang diintroduksi Moore (1978) mengenai kapasitas kelompok - kelompok sosial (socialfield) dalam menciptakan mekanisme - mekanis- 
me pengaturan sendiri (self- regulation) dengan disertai kekuatan - kekuatan pemaksa pentaatannya.

Karena itu, Griffiths kemudian mengadopsi pengertian pluralisme hukum dari Moore (1978). Sementara itu, hukum yang dimaksud dalam konsep pluralisme hokum Griffiths kemudian menjadi tidak terbatas pada sistem hukum negara, hukum kebiasaan, atau hukum agama saja, tetapi kemudian diperluas termasuk juga sistem normative yang berupa mekanisme makanisme pengaturan sendiri seperti yang diintroduksi Moore (1978), yaitu: Law is the self regulation of a 'semi-autonomous social field'(Tamanaha, 1992:25). Dalam perkembangan selanjutnya, konsep pluralisme hukum tidak lagi mengedepankan dikotomi antara sistem hukum Negara (state law) di satu sisi dengan sistem hukum rakyat (folk law) dan hukum agama (religious law) di sisi yang lain. Pada tahap perkembangan ini, konsep pluralisme hukum lebih menekankan pada interaksi dan ko-eksistensi berbagai sistem hukum yang mempengaruhi bekerjanya norma, proses, dan institusi hokum dalam masyarakat.

Berdasarkan pandangan diatas, maka hukum dalam perspektif antropologis merupakan aktivitas kebudayaan yang berfungsi sebagai sarana pengendalian social (social control), atau sebagai alat untuk menjaga keteraturan sosial (social order) dalam masyarakat. Karena itu, hukum di pelajari sebagai bagian yang integral dari kebudayaan secara keseluruhan, bukan sebagai suatu institusi otonom yang terpisah dari segi-segi kebudayaan yang lain (Pospisil, 1971) sehingga, untuk memahami tempat hukum dalam struktur masyarakat, maka harus dipahami terlebih dahulu kehidupan sosial dan budaya masyarakat tersebut secara keseluruhan.

Kenyatan ini memperlihatkan, bahwa hukum menjadi salah satu produk ke budayaan yang tidak terpisahkan dengan segi-segi kebudayaan yang lain, seperti politik, ekonomi, struktur dan organisasi sosial, ideologi, religi. Untuk memperlihatkan keterpautan hukum dengan aspek- 
aspek kebudayaan yang lain, maka menarik untuk mengungkapkan teori hukum sebagai suatu sistem (the legal system) yang diintroduksi Friedman (1975:14-5, 1984:5-7) seperti berikut:

1. Hukum sebagai suatu sistem pada pokoknya mempunyai 3 elemen, yaitu

(a) struktur sistem hokum (structure of legal system) yang terdiri dari lembaga pembuat undang- undang (legislatif), institusi pengadilan dengan strukturnya, lembaga kejaksaan dengan strukturnya, badan kepolisian negara, yang berfungsi sebagai aparat penegak hukum; (b) substansi sistem hukum (substance of legal system) yang berupa norma norma hukum, peraturan - peraturan hukum, termasuk pola - pola perilaku masyarakat yang berada di balik sistem hukum; dan (c) budaya hokum masyarakat (legal culture) seperti nilai - nilai, ide - ide, harapan - harapan dan kepercayaan - kepercayaan yang terwujud dalam perilaku masyarakat dalam mempersepsikan hukum.

2. Setiap masyarakat memiliki struktur dan substansi hukum sendiri. Yang menentukan apakah substansi dan struktur hukum tersebut ditaati atau sebaliknya juga dilanggar adalah sikap dan perilaku sosial masyarakatnya, dan karena itu untuk memahami apakah hukum itu menjadi efektif atau tidak sangat tergantung pada kebiasaan - kebiasaan (customs), kultur (culture), tradisi - tradisi (traditions), dan norma - norma informal (informal norms) yang diciptakan dan dioperasionalkan dalam masyarakat yang bersangkutan.

Dengan mengkaji komponen struktur hukum, substansi hukum, dan kultur hukum sebagai suatu sistem hukum, maka dapat dicermati bagaimana suatu sistem hokum bekerja dalam masyarakat, atau bagaimana sistem - sistem hukum dalam konteks pluralisme hukum saling berinteraksi dalam suatu bidang kehidupan sosial (social field) tertentu. Kultur hukum menjadi bagian dari kekuatan sosial yang menentukan efektif atau tidaknya hukum dalam kehidupan 
masyarakat; kultur hukum menjadi motor penggerak dan memberi masukan-masukan kepada struktur dan substansi hukum dalam memperkuat sistem hukum. Kekuatan social secara terus menerus mempengaruhi kinerja sistem hukum, walaupun kadang - kadang dapat merusak, memperbaharui, memperkuat, atau memilih lebih menampilkan segi-segi tertentu, sehingga untuk mengkaji komponen substansi, struktur, dan budaya hukum berpengaruh terhadap kinerja penegakan hukum, maka dapat dipahami suatu situasi bagaimana hukum bekerja sebagai suatu sistem dalam kehidupan masyarakat.

Karakter khas lain dari antropologi hukum adalah berbagai sistem hukum dalam masyarakat di berbagai belahan dunia di pelajari dengan memfokuskan pada proses-proses mikro (micro processes) yang secara empiris berlangsung dalam kehidupan masyarakat. Karena itu. metode holistik dalam mengkaji pluralisme hukum dalam masyarakat sangat memhantu menjelaskan mekanisme, prosedur, dan institusi-institusi hukum serta keterkaitannya dengan aspek politik, ekonomi, religi, organisasi sosial. ideologi. Implikasi dari karakteristik metodologi antropologi hukum seperti disebutkan di atas adalah : jika studi - studi mengenai fenomena hukum dalam masyarakat dilakukan untuk memperoleh pemahaman secara utuh-menyeluruh dan holistik, maka studi antropologi hukum harus difokuskan paling tidak pada empat aspek kajian pokok sebagai satu kesatuan, yaitu mulai dari kajian :

1. Proses Pembuatan Hukum (Law Making Process);

2. Norma Hukum / Peraturan Perundang- undangan (Legal Norms);

3. Pelaksanaan Hukum (Law Implemen- tation/Application); dan

4. Penegakan Hukum (Law Enforcement).

Kajian pada tingkatan proses pembuatan hukum akan memberi pemahaman 
bagaimana petarungan berbagai kepentingan ekonomi, politik, sosial, religi, termasuk ideologi partai dan tekanan dunia internasional (Negara - negara / lembaga -lembaga infernasional) mempengaruhi masa- masa perdebatan dan pengambilan keputusan untuk menyetujui (dari lembaga legislatif) dan mensahkan (dari lembaga ekskutif) suatu produk hukum negara (state law). Selain itu, akan diamati dan dicermati apakah proses pembuatan hukumnya sudah melalui mekanisme yang benar, seperti dimulai dengan membuat background paper, naskah akademik, baru kemudian menyusun rancangan undang-undangnya; apakah kemudian dalam proses tersebut dilakukan konsultasi publik (public consultation) oleh ekskutif dan dengar pendapat (hearing) sebagai cerminan dari prinsip transparansi dan partisipasi publik dengan melibatkan semua komponen stakeholders sebelum persetujuan oleh legislatif dan pengesahan oleh eksekutif dilakukan. Dengan demikian, proses-proses tersebut dan pertarungan kepentingan yang mendominasi proses tersebut dapat diketahui secara eksplisit memberi warna dan nuansa, jiwa dan semangat dari produk hukum yang dihasilkan seperti tercermin pada asas dan norma -norma hukumnya. 


\section{PENUTUP}

Berdasarkan urian tersebut diatas,dapat disimpulkan bahwa hukum pada dasarnya berbasis pada masyarakat. Maka salah satu metode khas dalam antropologi hukum adalah kerja lapangan (fieldwork methodology) untuk memahami eksistensi dan bekerjanya hukum dalam situasi normal maupun suasana sengketa. Oleh karena itu kasus - kasus sengketa sangat umum digunakan sebagai metode untuk menelusuri hukum masyarakat dalam studi antropologis mengenai hukum. Hal terjadi karena hokum bukan semata-mata sebagai suatu produk dari individu atau sekelompok orang dalam bentuk peraturan perundang-undangan, atau bukan sebagai suatu institusi yang terisolasi dari aspek-aspek kebudayaan yang lain, tetapi hukum merupakan produk dari suatu relasi sosial dalam sistem kehidupan masyarakat. Hukum adat di Indonesia tidak sama dengan antropologi hukum, karena hukum adat hanya salah satu dari sistem hukum rakyat (folk law atau customary law) yang menarik untuk dikaji melalui studi antropologi hukum, seperti juga sistem - sistem hukum rakyat asli (indigenous law) yang dapat ditemukan di Malaysia, Philipina, Thailand, Nepal, India, Australia, Amerika Latin, Afrika. Jadi, hukum adat (adat law) adalah sistem hukum khas Indonesia yang dapat dijadikan objek kajian untuk memahami sistem hukum rakyat yang secara empiris hidup dan berkembang dalam kehidupan masyarakat sebagai cerminan pluralisme hukum dalam masyarakat di berbagai wilayah di Indonesia. 


\section{DAFTAR PUSTAKA}

Darmini Roza dan Laurensius Arliman S, Peran Pemerintah Daerah Di Dalam Melindungi Hak Anak Di Indonesia, Masalah-Masalah Hukum, Volume 47, Nomor 1, 2018. https://doi.org/10.14710/mmh.47.1.2018.10-21

Laurensius Arliman S, Peranan Metodologi Penelitian Hukum di Dalam Perkembangan Ilmu Hukum di Indonesia, Soumatera Law Review, Volume 1, Nomor 1, 201. http://doi.org/10.22216/soumlaw.vli1.3346.

Laurensius Arliman S, Peran Badan Permusyawaratan Desa di Dalam Pembangunan Desa dan Pengawasan Keuangan Desa, Padjadjaran Journal of Law, Volume 4, Nomor 3, 2017. https://doi.org/10.15408/jch.v4i2.3433.

Laurensius Arliman S, Penanaman Modal Asing Di Sumatera Barat Berdasarkan UndangUndang Nomor 25 Tahun 2007 Tentang Penanaman Modal, Supremasi Hukum, Volume 1, Nomor 1, 2018. http://dx.doi.org/10.36441/hukum.v1i01.102.

Laurensius Arliman S, Memperkuat Kearifan Lokal Untuk Menangkal Intoleransi Umat Beragama Di Indonesia, Ensiklopedia of Journal, Volume 1, Nomor 1, 2018, https://doi.org/10.33559/eoj.v1i1.18.

Laurensius Arliman S, Perkawinan Antar Negara Di Indonesia Berdasarkan Hukum Perdata Internasional, Kertha Patrika, Volume 39, Nomor 3, 2017, https://doi.org/10.24843/KP.2017.v39.i03.p03.

Laurensius Arliman S, Partisipasi Masyarakat Di Dalam Pengelolaan Uang Desa PascaUndangUndang Nomor 6 Tahun 2014 Tentang Desa, Jurnal Arena Hukum, Volume 12, Nomor 2, 2019, https://doi.org/10.21776/ub.arenahukum.2019.01202.5.

Laurensius Arliman S, Mewujudkan Penegakan Hukum Yang Baik Di Negara Hukum Indonesia, Dialogica Jurnalica, Volume 11, Nomor 1, 2019, https://doi.org/10.28932/di.v11i1.1831.

Laurensius Arliman S, Mediasi Melalui Pendekatan Mufakat Sebagai Lembaga Alternatif Penyelesaian Sengketa Untuk Mendukung Pembangunan Ekonomi Nasional, UIR Law Review, Volume 2, Nomor 2, 2018, https://doi.org/10.25299/uirlrev.2018.vol2(02).1587

Laurensius Arliman S, Peranan Filsafat Hukum Dalam Perlindungan Hak Anak Yang Berkelanjutan Sebagai Bagian Dari Hak Asasi Manusia, Doctrinal, Volume 1, Nomor 2,2016.

Laurensius Arliman S, Ni Putu Eka Dewi, Protection of Children and Women's Rights in Indonesiathrough International Regulation Ratification, Journal of Innovation, Creativity and Change Volume 15, Nomor 6, 2021.

Laurensius Arliman S, Gagalnya Perlindungan Anak Sebagai Salah Satu Bagian Dari Hak Asasi Manusia Oleh Orang Tua Ditinjau Dari Mazhab Utilitarianisme, Jurnal Yuridis, Volume 3, Nomor 2, 2016, http://dx.doi.org/10.35586/.v3i2.180.

Laurensius Arliman S, Tantangan Pendidikan Kewarganegaraan Pada Revolusi 4.0, Jurnal Ensiklopedia Sosial Review, Volume 2, Nomor 3, $2020 .$. 